\title{
ANALISIS DISTRIBUSI SPASIAL SALINITAS AIRTANAH DI PULAU PRAMUKA, KEPULAUAN SERIBU, DKI JAKARTA
}

\author{
Ahmad Cahyadi, Muh Aris Marfai, Tommy Andryan Tivianto, Wulandari dan Wahyu Hidayat \\ Jurusan Geografi Lingkungan Fakultas Geografi Universitas Gadjah Mada \\ Email: ahmadcahyadi@geo.ugm.ac.id
}

INTISARI

\begin{abstract}
Sejak ditetapkan sebagai Ibukota Kabupaten Kepulauan Seribu, Pulau Pramuka mengalami perkembangan pesat. Perkembangan ini ditandai dengan semakin banyaknya jumlah penduduk, jumlah fasilitas kesehatan, permukiman, pariwisata serta fasilitas umum lain yang mendukung fungsinya sebagai ibukota Kabupaten. Perkembangan tersebut tentunya akan berdampak pada jumlah kebutuhan air, padahal karakteristik Pulau Pramuka sebagai pulau sangat kecil (luas kurang dari $100 \mathrm{~km}^{2}$ ) menyebabkan pulau ini memiliki jumlah sumberdaya air khususnya airtanah yang terbatas dan rawan terhadap intrusi air laut. Penelitian ini bertujuan untuk mengetahui (1) sebaran spasial salinitas airtanah di Pulau Pramuka dan (2) mengetahui kendala-kendala dalam pemetaan sebaran spasial salinitas menggunakan analisis daya hantar listrik. Penelitian dilakukan dengan pengukuran daya hantar listrik di lapangan pada air sumur dengan menggunakan EC meter. Hasil pengukuran kemudian dianalisis dengan geostatistik kriging. Hasil penelitian menunjukkan bahwa airtanah di Pulau Pramuka didominasi oleh air payau dan asin. Hal ini menunjukkan bahwa intrusi air laut telah menyusup ke lensa airtanah. Selain itu, dalam penelitian ini diketahui bahwa dalam pemetaan salinitas airtanah pada pulau sangat kecil menggunakan EC meter memiliki kendala berupa keterbatasan alat yang hanya mampu mengukur salinitas sampai dengan $20.000 \mu \mathrm{mhos}$, sehingga dalam pemetaan tersebut dibutuhkan analisis laboratorium untuk mengukur air yang memiliki salinitas lebih dari kemampuan pengukuran EC meter.
\end{abstract}

Kata kunci: Airtanah, Distribusi Spasial, Salinitas, Kendala Pemetaan, Pulau Sangat Kecil

\section{A. PENDAhUluAN}

Pulau kecil (pulau dengan ukuran kurang dari $2.000 \mathrm{~km}^{2}$ (Falkland, 1991)) memiliki kondisi hidrologi yang unik. Luas tangkapan hujan yang sedikit menyebabkan jumlah air yang dapat dimanfaatkan menjadi sedikit (Falkland, 1992). Selain itu, pulau kecil yang biasanya memiliki ketinggian daratan yang rendah, menyebabkan tidak memungkinkan terjadinya jenis hujan orografis, sehingga jumlah curah hujan di pulau kecil biasanya lebih sedikit dibandingkan dengan pulau besar yang memiliki pegunungan atau gunungapi (Hehanusa dan Bakti, 2005). Faktor lain yang menyebabkan terjadinya keterbatasan sumberdaya air di pulau kecil adalah adanya interaksi antara air tawar dengan air laut yang membentuk lensa airtanah. Lensa airtanah ini merupakan cadangan air tawar di pulau kecil yang besarnya sangat tergantung dengan material penyusun batuan, luas pulau, topografi pulau, curah hujan, serta kondisi perairan laut di sekitar pulau kecil (bathimetri, gelombang dan arus).

Airtanah dan air hujan merupakan sumber air yang potensial di pulau kecil (Falkland, 1993). Pemanfaatan air hujan biasanya dilakukan dengan melakukan pemanenan melalui atap rumah yang ditampung ke dalam bak penampung, atau lebih dikenal dengan penampung air hujan (PAH). Pemanfaatan airtanah biasanya dilakukan dengan membuat sumur gali, atau pada beberapa pulau kecil airtanah dimanfaatkan dalam bentuk pemanfaatan mataair. Namun demikian, pemanfaatan sumberdaya airtanah sering kali terkendala dengan adanya kerawanan pencemaran yang tinggi serta adanya intrusi air laut (Cahyadi, 2012).

Penelitian ini bertujuan untuk mengetahui (1) sebaran spasial salinitas airtanah di Pulau Pramuka, Provinsi DKI Jakarta dan (2) mengetahui kendala-kendala dalam pemetaan sebaran spasial salinitas menggunakan analisis daya hantar listrik. Kajian ini diharapkan dapat menjadi masukan dalam pengelolaan Pulau Pramuka yang sejak Tahun 2003 ditetapkan sebagai ibukota Kabupaten Kepulauan Seribu. Kondisi tersebut telah menyebabkan berkembangnya Pulau Pramuka untuk dapat mendukung fungsinya sebagai lbukota. Perkembangan tersebut ditunjukkan dengan semakin banyaknya lahan terbangun, jumlah penduduk serta jumlah fasilitas umum dan pariwisata.

\section{B. METODE PENELITIAN}

Penelitian ini dilakukan dengan pengukuran daya dantar listrik (DHL) menggunakan EC meter pada airtanah yang diambil dari sumur gali yang ditemukan di Pulau Pramuka. Hasil pengukuran 
Seminar Nasional Pendayagunaan Informasi Geospatial untuk Optimalisasi Otonomi Daerah Universitas Muhammadiyah Surakarta, 2013

kemudian diplot berdasarkan koordinat lokasi pengambilan. Pemetaan sebaran spasial dilakukan dengan melakukan interpolasi dengan metode geostatistik kriging. Metode ini menurut (Hadi, 2005) merupakan metode yang cocok untuk pemetaan airtanah. Hasil interpolasi kemudian dianalisis untuk menentukan kualitas air berdasarkan salinitasnya. Penentuan kelas kualitas airtanah berdasarkan salinitasnya dilakukan dengan klasifikasi yang dibuat oleh Suherman (2007). Klasifikasi tersebut ditunjukkan dalam Tabel 1.

Tabel 3.2. Klasifikasi DHL untuk Menentukan Kualitas Air Beradasarkan Salinitasnya

\begin{tabular}{|c|c|}
\hline Kualitas Air & DHL $(\boldsymbol{\mu S} / \mathbf{c m})$ \\
\hline Tawar & $>1.500$ \\
\hline Agak Payau & $>1.500-\leq 5.000$ \\
\hline Payau & $>5.000-\leq 15.000$ \\
\hline Asin & $>50.0000$ \\
\hline Brine & \\
\hline Sun
\end{tabular}

Sumber: Suherman, 2007

\section{HASIL DAN PEMBAHASAN}

interpolasi data daya hantar listrik menunjukkan bahwa sebaran nilai DHL di Pulau Pramuka berkisar antara $1.500 \mu$ mhos sampai dengan $50.000 \mu$ mhos (Gambar 1). Meskipun demikian, hasil pengukuran maksimum yang dihasil di lapangan hanya sampai dengan nilai $20.000 \mu$ mhos. Hal ini terjadi akibat adanya ekstrapolasi yang dilakukan dalam pengolahan menggunakan software.

Hasil interpolasi menunjukkan bahwa nilai DHL yang rendah $(1.500 \mu$ mhos $-5.000 \mu$ mhos $)$ terdapat pada bagian tengah pulau. Kondisi tersebut disebabkan karena pada bagian tengah pulau relatif memiliki pengaruh dari air laut yang lebih sedikit. Hasil ini juga menunjukkan bahwa lensa aitrtanah di Pulau Pramuka sudah banyak terpengaruh oleh intrusi air laut. Hal ini terjadi karena sedikitnya jumlah air yang meresap ke dalam sistem airtanah serta besarnya pengaruh arus dan gelombang laut. Sedikitnya jumlah air yang meresap disebabkan karena luas pulau yang kecil (16 hektar) dan jumlah curah hujan yang sedikit. Selain itu, jumlah resapan yang sedikit disebabkan akibat penggunaan lahan terbangun yang dominan dan dibangunnya drainase yang membuang air hujan langsung ke laut.

Berdasarkan nilai dari daya hantar listrik yang telah dipetakan, maka diketahui bahwa kualitas airtanah di Pulau Pramuka terdiri dari kualitas agak payau, payau dan asin (Gambar 2). Berdasarkan kualitas airtanah yang terpetakan, maka dapat diketahui bahwa intrusi telah menyebabkan lensa airtanah di Pulau Pramuka terpisah-pisah. Bahkan, berdasarkan kualitas airtanah yang ada, maka dapat disimpulkan bahwa kualitas airtanah di Pulau Pramuka sudah sangat buruk. Hal ini karena tidak ada lagi airtanah dengan kualitas tawar.

Penggunaan metode pengukuran DHL untuk pemetaan salinitas airtanah memiliki kelemahan berupa batas pengukuran sebesar 20.000 umhos. Namun demikian, untuk pemetaan potensi airtanah, metode ini dapat digunakan. Hal ini karena kualitas airtanah yang dapat dimanfaatkan memiliki range kurang dari batas pengukuran alat.

Pemetaan salitasn airtanah yang memungkinkan dilakukannya pengukuran dengan nilai $>20.000$ $\mu$ mhos dapat dilakukan dengan menggunakan analisis di laboratorium. Namun demikian, metode yang digunakan tidak lagi dengan menggunakan nilai $\mathrm{DHL}$, namun dapal dilakukan dengan menggunakan unsur penciri seperti nilai klorida dan natrium, atau perbandingan unsur tersebut dengan unsur kalsium dan bikarbonat. 


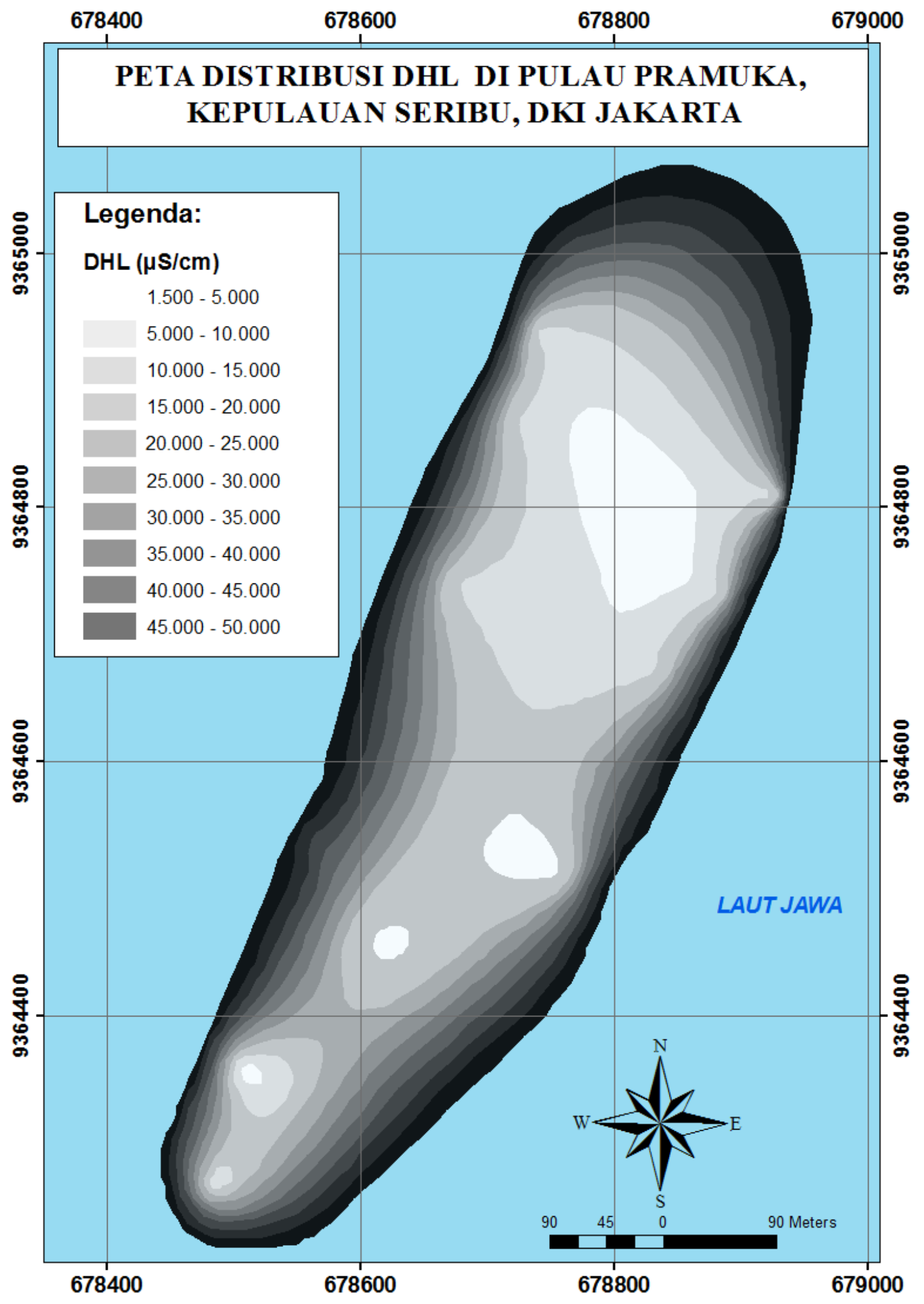

Gambar 1. Distribusi Spasial Nilai Daya Hantar Listrik Airtanah di Pulau Pramuka 


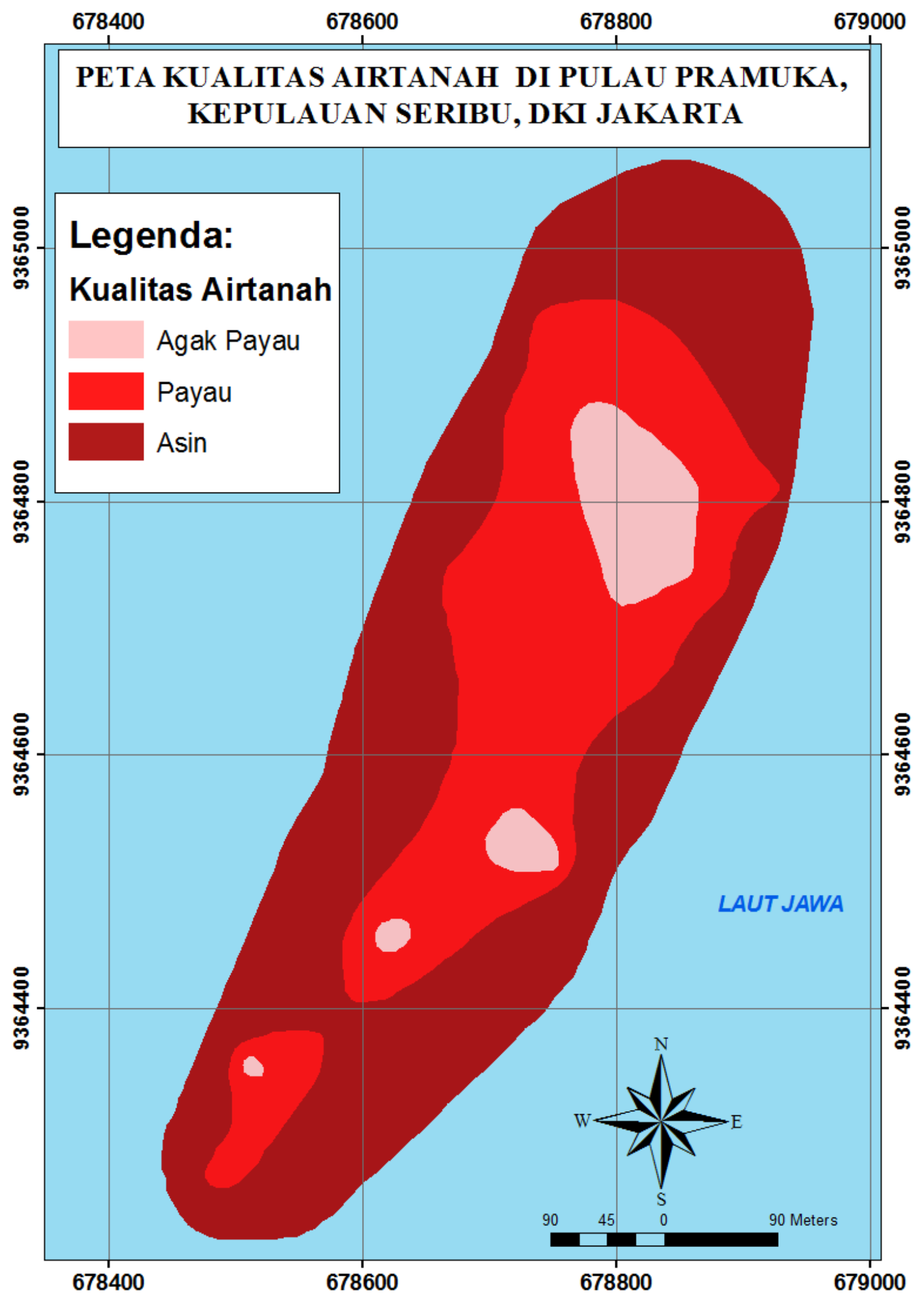

Gambar 2. Distribusi Spasial Kualitas Airtanah di Pulau Pramuka 


\section{PENUTUP}

Berdasarkan hasil penelitian yang telah dilakukan, maka diketahui bahwa kualitas airtanah di Pulau Pramuka didominasi oleh air payau dan asin. Hal ini menunjukkan bahwa intrusi air laut telah menyusup ke lensa airtanah. Selain itu, dalam penelitian ini diketahui bahwa dalam pemetaan salinitas airtanah pada pulau sangat kecil menggunakan EC meter memiliki kendala berupa keterbatasan alat yang hanya mampu mengukur salinitas sampai dengan $20.000 \mu$ mhos, sehingga dalam pemetaan tersebut dibutuhkan analisis laboratorium untuk mengukur air yang memiliki salinitas lebih dari kemampuan pengukuran EC meter.

\section{E. PENGAKUAN}

Penelitian ini merupakan sebagian dari penelitian berjudul "Kajian Potensi Sumberdaya Air Pulau Sangat Kecil: Studi Kasus Pulau Koral Pramuka, Kabupaten Kepulauan Seribu, DKI Jakarta". Penelitian ini didanai oleh Fakultas Geografi Universitas Gadjah Mada melalui Dana Penerimaan Negara Bukan Pajak, Fakultas Geografi Universitas Gadjah Mada Tahun Anggaran 2013.

\section{DAFTAR PUSTAKA}

Afadlal; Wijonarko, S.; Meifina; Septi, A.; Ongkosongo, A.E. dan Ongkosongo, O.S.R., 2011a, Kondisi Lingkungan Sosial, Ekonomi dan Budaya di Pulau Pramuka, dalam Ongkosongo, O.S.R.; Wijonarko, S. Dan Afadlal. 2011. Rona Lingkungan Pulau Pramuka. Jakarta: Lembaga IImu Pengetahuan Indonesia (LIPI), Pusat Penelitian Oseanografi, Balai Dinamika Laut, Kolompok Penelitian Geologi Laut.

Cahyadi, A. 2012. Permasalahan Sumberdaya Air Pulau Kecil. Prosiding Seminar Lingkungan Hidup 2012. Magister Ilmu Lingkungan, Universitas Diponegoro Semarang.

Falkland, C. A. 1991. Hydrology and Water Resources of Small Island: A Practical Guide. Paris: UNESCO.

Falkland, C. A. 1992. Small Tropical Island: Water Resources of Paradises Lost. Paris: UNESCO.

Falkland, C. A. 1993. Hydrology and Water Management in Small Tropical Island. Proceeding of The Yokohama Symposium on Hydrology on Warm Humid Regions. July, 1993.

Hadi, I. 2005. Metode Kriging untuk Memetakan Konfigurasi Air Tawar Pulau Kecil. dalam Hehanusa, P.E. dan Bakti, H. 2005. Sumber Daya Air di Pulau Kecil. Bandung: Lembaga Ilmu Pengetahuan Indonesia, Pusat Penelitian Geoteknologi.

Hehanusa, P.E. dan Bakti, Hendra. 2005. Sumber Daya Air di Pulau Kecil. Bandung: LIPI Press.

Suherman, Dadang. 2007. Mata Air Sebagai Sumber Air Bersih di Pulau Kai-Kecil, maluku Tenggara. dalam Hehanusa, P.E. dan Bhakti, H. 2004, (eds). Sumber Daya Air di Pulau Kecil. Bandung: Lembaga IImu Pengetahuan Indonesia, Pusat Penelitian Geoteknologi. 